\title{
Review \\ Mucosal Mast Cells as Key Effector Cells in Food Allergies
}

\author{
Nobuhiro Nakano *(D) and Jiro Kitaura
}

\author{
Atopy (Allergy) Research Center, Juntendo University Graduate School of Medicine, Tokyo 113-8421, Japan; \\ j-kitaura@juntendo.ac.jp \\ * Correspondence: nbnakano@juntendo.ac.jp; Tel.: +81-3-5802-1591
}

Citation: Nakano, N.; Kitaura, J. Mucosal Mast Cells as Key Effector Cells in Food Allergies. Cells 2022, 11, 329. https://doi.org/10.3390/ cells11030329

Academic Editor:

Yoshimichi Okayama

Received: 21 December 2021

Accepted: 18 January 2022

Published: 19 January 2022

Publisher's Note: MDPI stays neutral with regard to jurisdictional claims in published maps and institutional affiliations.

Copyright: (C) 2022 by the authors. Licensee MDPI, Basel, Switzerland. This article is an open access article distributed under the terms and conditions of the Creative Commons Attribution (CC BY) license (https:// creativecommons.org/licenses/by/ $4.0 /)$.

\begin{abstract}
Mucosal mast cells (MMCs) localized in the intestinal mucosa play a key role in the development of IgE-mediated food allergies. Recent advances have revealed that MMCs are a distinctly different population from connective tissue mast cells localized in skin and other connective tissues. MMCs are inducible and transient cells that arise from bone marrow-derived mast cell progenitors, and their numbers increase rapidly during mucosal allergic inflammation. However, the mechanism of the dramatic expansion of MMCs and their cell functions are not well understood. Here, we review recent findings on the mechanisms of MMC differentiation and expansion, and we discuss the potential for the inducers of differentiation and expansion to serve as targets for food allergy therapy. In addition, we also discuss the mechanism by which oral immunotherapy, a promising treatment for food allergy patients, induces unresponsiveness to food allergens and the roles of MMCs in this process. Research focusing on MMCs should provide useful information for understanding the underlying mechanisms of food allergies in order to further advance the treatment of food allergies.
\end{abstract}

Keywords: mucosal mast cells; notch signaling; TGF- $\beta$; food allergy; oral immunotherapy

\section{Introduction}

Humans have long suffered from food allergies. Hippocrates (460-377 BC), an ancient Greek physician, wrote about a suspected case of allergy to cheese [1]. The principal treatment for food allergies is the identification and avoidance of the causative food, which has remained largely unchanged from ancient times to the present. However, these approaches create a serious problem with food energy intake [2]. Therefore, the development of therapeutic agents and treatments for food allergies is in high demand, but to achieve this, we need to understand the underlying mechanisms.

Food allergies are classified into three groups according to the immunological mechanism: IgE-mediated, non-IgE-mediated, and mixed. Typical food allergies are IgE-mediated, and thus the main symptoms are caused by immediate hypersensitivity reactions in which food allergen-specific IgE and mast cells play a central role. In some non-IgE-mediated allergies, such as pseudo-allergies, mast cell activation also plays an important role in the onset of allergic symptoms [3-5]. In developed countries, the prevalence of food allergies is $6 \%$ to $10 \%$ in infants and $2 \%$ to $5 \%$ in adults [6-9], indicating that they are more common in children. However, it has recently been demonstrated that some patients with irritable bowel syndrome (IBS) have abdominal pain caused by local IgE-mediated food allergy reactions [10]. The prevalence of IBS in developed countries is approximately $10 \%$ to $15 \%$ and is more common in adults. More than $50 \%$ of patients with IBS have symptoms triggered by a meal, despite negative results of serum food allergen-specific IgE antibodies and skin prick tests [11,12]. Recent studies have shown that many of these patients are negative for food allergen-specific IgE in serum but positive for the intestinal mucosa, which leads to a local IgE-mediated food allergy reaction [10,12]. Based on these findings, Aguilera-Lizarraga et al. [10] proposed a new disease concept called "food-induced disorders mediated by mast cell activation". IBS, in which foods are involved in the onset of symptoms, is part of 
a spectrum of food-induced disorders, and systemic food allergy is at extreme end of the spectrum.

Many studies using animal models have shown that mast cells in the intestinal mucosa are the major effector cells in IgE-mediated food-induced disorders, including food allergies [10,13-16]. Therefore, intestinal mucosal mast cells are an attractive target for therapeutic intervention in those diseases. In this review, we summarize the differentiation mechanisms and functions of intestinal mucosal mast cells and discuss the possibility of treating food-induced disorders by regulating them.

\section{Mucosal Mast Cells}

Mast cells are categorized into two types according to the staining patterns and anatomical locations: connective tissue-type and mucosal-type (Table 1).

Table 1. Characteristics of mast cell subtypes.

\begin{tabular}{|c|c|c|c|}
\hline & Mucosal-Type & Connective Tissue-Type & Ref. \\
\hline Mouse & Mucosal Mast Cell (MMC) & Connective Tissue Mast Cell (CTMC) & \\
\hline Size & Smaller $(5-10 \mu \mathrm{m})$ & Larger $(10-20 \mu \mathrm{m})$ & [17] \\
\hline Protease & mMCP-1 ${ }^{1}, \mathrm{mMCP}-2$ & $\begin{array}{c}\mathrm{mMCP}-4, \mathrm{mMCP}-5, \mathrm{mMCP}^{-6}, \mathrm{mMCP}-7 \\
\mathrm{CPA}^{2}{ }^{2}\end{array}$ & [18] \\
\hline Proteoglycan & Chondroitind sulfate di-B, A, E & $\begin{array}{l}\text { Chondroitind sulfate E } \\
\text { Heparin }\end{array}$ & [19] \\
\hline Biogenic Amine & $\begin{array}{c}\text { Histamine (Low, }<1 \text { pg per cell) } \\
\text { Serotonin }\end{array}$ & $\begin{array}{c}\text { Histamine (High, }>15 \text { pg per cell) } \\
\text { Serotonin }\end{array}$ & [19] \\
\hline $\begin{array}{l}\text { Cell surface Marker } \\
\text { Specific Marker }\end{array}$ & $\begin{array}{c}\text { FceRI, c-Kit/CD117, ST2 } \\
\alpha \text { E integrin/CD103 }\end{array}$ & $\begin{array}{c}\text { FceRI, c-Kit/CD117, ST2 } \\
\text { Mrgprb2 }^{3}\end{array}$ & {$[3,18,20]$} \\
\hline Life Span & Few weeks ( 40 days) & $9-18$ months & [21] \\
\hline Progenitor & $\begin{array}{l}\text { Bone marrow-derived } \beta 7 \\
\text { integrin }^{+} \mathrm{MCp}^{4}\end{array}$ & Fetal-derived $\beta 7$ integrin $^{+} \mathrm{MCp}$ & [22-24] \\
\hline Human & $\mathrm{MC}_{\mathrm{T}}$ & $\mathrm{MC}_{\mathrm{TC}}$ & \\
\hline Protease & Tryprase & $\begin{array}{l}\text { Tryptase, Chymase } \\
\text { CPA3, Cathepsin G }\end{array}$ & [25] \\
\hline Proteoglycan & Heparin & Heparin & {$[18,26]$} \\
\hline Progenitor & $\mathrm{CD} 34^{+} \beta 7$ integrin $^{+} \mathrm{MCp}$ & $\mathrm{CD} 34^{+} \beta 7$ integrin $^{+} \mathrm{MCp}$ & {$[27,28]$} \\
\hline
\end{tabular}

\subsection{Mouse Mast Cell Subtypes}

Mouse connective tissue mast cells (CTMCs), which are located around venules and nerve endings in most connective tissues, contain heparin in the granules and are therefore stained metachromatically by dyes such as toluidine blue, alcian blue, safranin $\mathrm{O}$, and berberine sulphate $[18,23,24,29-32]$. In addition, CTMCs are characterized by the expression of mouse mast cell proteases (mMCP)- $4,-5,-6$, and -7 , as well as carboxypeptidase A3 (CPA3). In contrast, mouse mucosal mast cells (MMCs), which are located inside the epithelia of the intestinal and respiratory mucosa, lack heparin in the granules and are difficult to detect with standard histological staining protocols [18,29-32]. However, the expression of mMCP-1 and -2 is a characteristic feature of MMCs, and these may be appropriate markers for immunohistochemical staining. In addition, MMCs express $\alpha \mathrm{E}$ integrin/CD103 on the cell surface [18-20]. The $\alpha \mathrm{E}$ integrin is paired with the $\beta 7$ integrin to form the heterodimer $\alpha \mathrm{E} \beta 7$ that binds to epithelial-associated E-cadherin [33]. The expression of this adhesion molecule may contribute to the accumulation of MMCs in the mucosal tissues.

Furthermore, the lifespan is notably different between CTMCs and MMCs. This may be based on differences in the progenitors of each subtype. CTMCs are long-lived tissue-resident cells derived from fetal-derived progenitors and maintained locally by self- 
proliferation [19,21]. However, MMCs are inducible and transient cells that arise from bone marrow-derived mast cell progenitors (MCp), which have been identified as lineage ${ }^{-} \mathrm{c}^{-}$ $\mathrm{Kit}^{+} \mathrm{Sca}-1^{-} \mathrm{Ly}_{6 c^{-}} \mathrm{Fc}_{\mathrm{RI}} \alpha^{-} \mathrm{CD} 27^{-} \beta 7$-integrin ${ }^{+} \mathrm{ST} 2^{+}[32,34]$. Taken together, MMCs are a distinctly different population from CTMCs; however, their differentiation process and detailed functions are not fully understood.

\subsection{Human Mast Cell Subtypes}

In humans, mast cells expressing both tryptase and chymase $\left(\mathrm{MC}_{\mathrm{TC}}\right)$ and mast cells expressing tryptase without chymase $\left(\mathrm{MC}_{\mathrm{T}}\right)$ are considered to correspond to mouse CTMCs and MMCs, respectively [19]. Although the distribution of human mast cell subtypes is not as strictly restricted as in mice, $\mathrm{MC}_{\mathrm{T}} \mathrm{s}$ constitute approximately $80 \%$ of mast cells in the intestinal mucosa [35]. In addition, proteome analyses have shown that human and mouse mast cell functions are evolutionarily conserved and very similar [36]. Intestinal mast cells are found throughout the gastrointestinal tract and normally account for 2-3\% of mononuclear cells in the lamina propria. Ehrsam et al. [37] have recently reported the number and distribution of mast cells in the pediatric gastrointestinal tract in healthy individuals, as well as in patients with food allergies. Importantly, mast cell hyperplasia and higher tryptase concentrations in the intestinal mucosa are associated with allergic inflammation of the mucosa in patients with food allergies and IBS [38,39]. However, since a committed human MCp, which is identified as $\mathrm{CD}^{+} 4^{+} \beta 7$-integrin ${ }^{+}$, is found in both adult peripheral blood [27] and fetal cord blood [28], it is currently unclear how $\mathrm{MC}_{\mathrm{TC}} \mathrm{s}$ and $\mathrm{MC}_{\mathrm{T}} \mathrm{s}$ are maintained in each tissue.

Taken together, the activation of intestinal mucosal mast cells (mouse MMCs and human $\mathrm{MC}_{\mathrm{T}}$ ) plays a key role in the development of IgE-mediated food allergies.

\subsection{Mediators Released by Activated MMCs}

In the immediate phase of IgE-mediated food allergy, MMCs function as major effector cells through the IgE-dependent release of a wide variety of chemical mediators, such as biogenic amine, lipid mediators, proteases, and inflammatory cytokines [40,41]. Histamine, which is a major amine released from activated mast cells, leads to vasodilation for the recruitment of leukocytes, which in some cases triggers anaphylaxis [41]. In addition, histamine causes abdominal pain by binding histamine receptors on sensory neurons in the gut [10]. Serotonin, also a biogenic amine released from activated mast cells, contributes to the pathophysiology of anaphylaxis and allergic diarrhea $[13,41]$. The lipid mediator platelet-activating factor (PAF) also contributes to the induction of anaphylaxis and allergic diarrhea $[13,41]$. Prostaglandin $\mathrm{D}_{2}$ (PGD2), a lipid mediator produced in large quantities by mast cells, accelerates type 2 inflammation by accumulating inflammatory cells in mouse models of asthma [42]. In contrast, in a mouse model of IgE-mediated food allergies, the deficiency of PGD2 results in mast cell hyperplasia and exacerbates food allergen-induced allergic reactions [16]. Activated MMCs immediately release MMC-specific proteases mMCP-1 and mMCP-2 (in humans, tryptase is released from $\mathrm{MC}_{\mathrm{T}}$ ). Although the effects of these proteases on the pathogenesis of food allergies are unknown, they are much more stable in the blood than histamine and are useful as markers of $\mathrm{MMC}$ or $\mathrm{MC}_{\mathrm{T}}$ activation $[13,43]$.

The late-phase allergic response, which occurs several hours after the immediate phase, is characterized by the infiltration of inflammatory cells into tissues. The migration of these cells is stimulated by cytokines released from activated MMCs in the immediate phase. Eosinophils are mobilized by IL- 5 released by mast cells, and neutrophils and lymphocytes are attracted by TNF- $\alpha$, causing inflammation and tissue destruction $[40,44]$. IL-13 is involved in Th2 development, B cell proliferation and isotype switching, and goblet cell hyperplasia with mucus hypersecretion. Importantly, it has been demonstrated that IL-13 released by mast cells contributes to the pathogenesis of IgE-mediated food allergies in mice [45]. 
Mas-related G protein-coupled receptor-X2 (MRGPRX2) (murine ortholog, Mrgprb2) is known as a receptor that causes IgE-independent mast cell activation. The receptor recognizes a broad range of cationic ligands, including certain types of drugs, host defense peptides (such as LL-37), and neuropeptides [3,5]. Importantly, the receptor is expressed on CTMCs, but not on MMCs (Table 1). Thus, pseudo-allergic reactions triggered by these molecules, even those ingested orally, may differ from IgE-dependent food allergies in the profile of secreted mediators.

\subsection{Biomarkers of Food Allergies Derived from Activated Mast Cells}

As mentioned above, multiple mediators are released from activated mast cells, including MMCs, during the effector phase of IgE-mediated food allergies. Some of these mediators are useful as biomarkers for objectively detecting allergic reactions in patients with food allergies. The biomarkers in blood or urine are important for the accurate detection of allergic reactions caused by oral food challenge, which is the gold standard for the diagnosis of food allergies and for the clinical diagnosis of anaphylaxis. Histamine is a typical mediator released by IgE-mediated mast cell degranulation. However, in order to properly measure plasma histamine levels, it is necessary to obtain a blood sample within 15 and 60 min after the onset of anaphylactic symptoms. In addition, special handling of the blood sample is required [46]. In contrast, urinary histamine and its metabolite, N-methylhistamine, can be measured in samples obtained $24 \mathrm{~h}$ after the onset of symptoms [46,47]. Tryptase is also a useful mediator for diagnosing of anaphylaxis. In particular, serum total tryptase levels are strongly associated with insect sting-triggered anaphylaxis $[48,49]$. However, tryptase levels are lower in MMCs (or $\mathrm{MC}_{\mathrm{T}}$ ) than in cutaneous and perivascular CTMCs (or $\mathrm{MC}_{\mathrm{TC}}$ ); thus, anaphylactic reactions and increased tryptase levels elicited by food allergies may be weaker than those elicited by insect sting or intravenous drugs [50]. Recently, a urinary PGD2 metabolite, 11,15-dioxo- $9 \alpha$-hydroxy2,3,4,5-tetranorprostan-1,20-dioic acid, was reported to be a useful diagnostic index of food allergies in both mice and humans [51,52]. Moreover, recent metabolomic analyses reveal many promising candidates for food allergy biomarkers [53]. Crestani et al. [54] show that multifood allergies are associated with tryptophan, an important metabolite in the production of serotonin, and 1-arachidonoyl-GPD, a metabolite upstream of PAF. These biomarkers are released at different times after the activation of mast cells. Therefore, it is desirable to have many biomarkers that can be used for diagnosis.

\section{Inducers of MMC Differentiation}

\subsection{Cytokines}

In an experimental IgE-mediated food allergy mouse model, intestinal MMCs are dramatically and rapidly expanded by repeated oral administration of food allergens to mice sensitized to the allergen. MMCs arise from bone marrow-derived MCp that are recruited to mucosal tissues in response to T cell-mediated type 2 allergic inflammation, such as IgE-mediated food allergy [32,34]. The differentiation of MCp into mature MMCs in situ indicates that there are some inducers of MMC differentiation in the mucosal tissues. Transforming growth factor- $\beta$ (TGF- $\beta$ ) is known to induce the expression of MMC-specific proteases, mMCP-1 and -2, and the cell surface CD103 in in vitro culture conditions [20,55-57]. Single-cell RNA sequencing of MMCs isolated from mouse models of allergic lung inflammation strongly suggests the involvement of TGF- $\beta$ in the differentiation of MMCs in vivo [32]. Therefore, TGF- $\beta$ is a promising candidate as an MMC differentiation inducer (Figure 1). In addition, it has also been reported that IL-10 induces MMC-specific protease expression in bone marrow-derived mast cells (BMMCs) [58,59] (Figure 1). TGF$\beta$ and IL-10 are important cytokines for the differentiation and maintenance of various immune cells belonging to the mucosal immune system, such as $\mathrm{CD} 103^{+}$dendritic cells and regulatory T cells (Treg) [60-62]. This implies that MMCs are also members of the mucosal immune system. 


\subsection{Notch Ligands}

In addition to those cytokines, we previously showed that Notch ligands are potent inducers of MMC differentiation [63] (Figure 1). In mammals, four Notch receptors, Notch14, which are epidermal growth factor-like transmembrane receptors, have been identified and are activated upon interaction with four transmembrane ligands (Jagged1, Jagged2, Delta-like 1 (DLL1), and DLL4). Notch receptor-mediated signaling (Notch signaling) is transmitted into the nucleus of recipient cells through cell-cell contact and regulates various cell fate determinations, such as lymphocyte development $[64,65]$. Mouse mast cells constitutively express Notch1 and Notch2 on the cell surface [66]. We found that when mouse BMMCs, immature mast cells, were co-cultured with a $\mathrm{CHO}$ cell line expressing the Notch ligand, the expression of MMC markers was induced in BMMCs. Notably, the gene expression profile of intestinal MMCs isolated from the small intestine of naive mice was closer to MMC-like cells generated in the presence of a Notch ligand than MMClike cells generated in the presence of TGF- $\beta$. Moreover, the co-culture of BMMCs with cells comprising the mouse intestinal mucosa, which express Notch ligands in some cells, induced the expression of MMC markers in BMMCs in a Notch signaling-dependent manner [63]. Therefore, signals provided by TGF- $\beta$, IL-10, and Notch ligands are predicted to be involved in MMC differentiation in the intestinal mucosa.

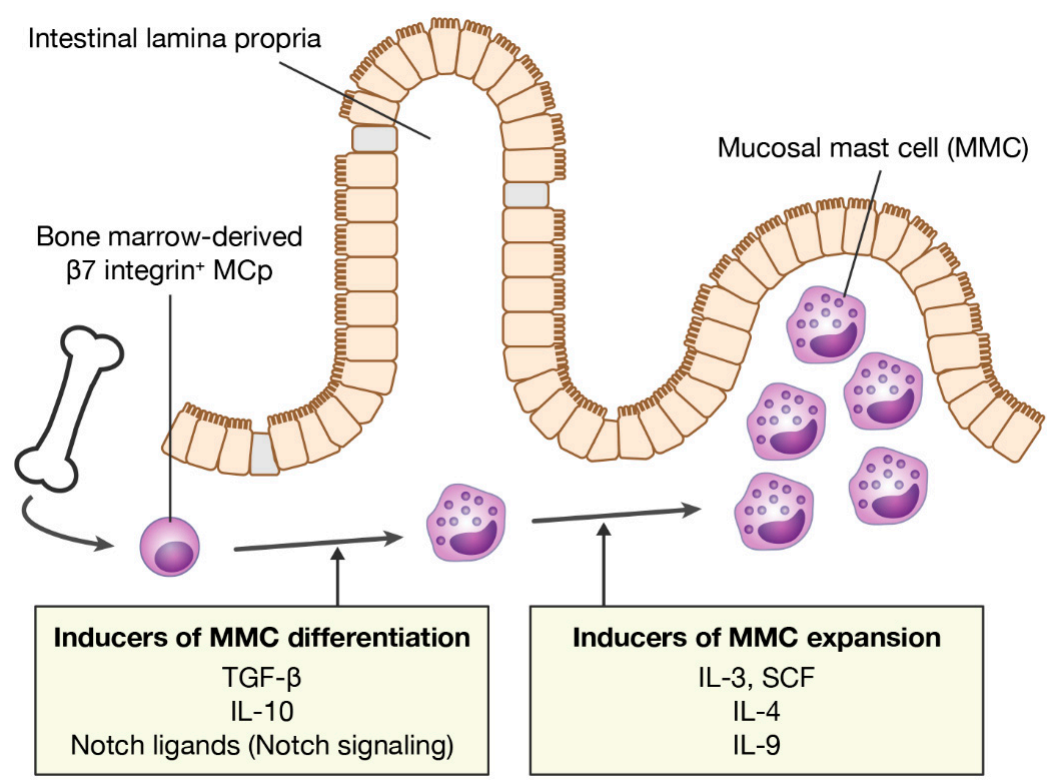

Figure 1. Inducers of MMC differentiation and expansion. MMCs differentiate from bone marrowderived MCps in mucosal tissues. MMC numbers increase rapidly during allergic inflammation. MMC, mucosal mast cell; MCp, mast cell progenitor; TGF- $\beta$, transforming growth factor- $\beta$; SCF, stem cell factor.

\section{Molecular Mechanisms of MMC Differentiation}

Canonical TGF- $\beta$ signaling is mediated by SMAD family proteins, which translocate to the nucleus and act as transcription factors. Mcpt1 and Mcpt2 genes, which encode MMCspecific proteases mMCP-1 and mMCP-2, respectively, have SMAD-responsive motifs and GATA motifs upstream of them. The GATA motif is a consensus nucleotide sequence to which GATA transcription factors bind directly. Kasakura et al. [57] have revealed that TGF$\beta$ induces the transcription of Mcpt1 and Mcpt 2 genes by mobilizing SMAD4 and GATA2 to those elements and motifs in BMMCs. In addition, the human ITGAE gene, which encodes CD103, has SMAD-responsive motifs and NFAT binding sites on both the promoter and enhancer. TGF- $\beta$ induces the transcription of the ITGAE gene by mobilizing SMAD3 and the transcription factor NFAT- 1 to the motifs and sites in human CD8 ${ }^{+} \mathrm{T}$ cells [67]. Thus, TGF- $\beta$ directly induces the transcription of the MMC marker genes, suggesting that it plays a central role in the differentiation of MMCs. 
So how does Notch signaling induce MMC differentiation? What is the relationship between Notch and TGF- $\beta$ signaling? To address these questions, we studied the molecular mechanisms by which Notch signaling induces MMC differentiation using mouse BMMCs. We first showed that the expression levels of MMC markers were synergistically enhanced in BMMCs by a combination of Notch ligand and TGF- $\beta$. Interestingly, Notch-mediated MMC marker expression was inhibited by a selective inhibitor of the TGF- $\beta$ type I receptor (i.e., a TGF- $\beta$ signaling inhibitor), and TGF- $\beta$-mediated MMC marker expression was inhibited by a $\gamma$-secretase inhibitor (i.e., a Notch signaling inhibitor). These results indicate that Notch and TGF- $\beta$ signaling function interdependently in the expression of MMC markers. In addition, Notch-mediated MMC marker expression in BMMCs was suppressed by the knockdown of SMAD4 expression using siRNA. Therefore, Notch signaling induces marker expression in a SMAD-dependent manner. However, Notch signaling did not upregulate TGF- $\beta$ production, TGF- $\beta$ receptor expression, or phosphorylation of SMADs in BMMCs, indicating that Notch signaling does not directly enhance TGF- $\beta$ signaling. We found that SMADs were always weakly phosphorylated in BMMCs by TGF- $\beta$ contained in the medium, even without the addition of TGF- $\beta$. This was confirmed by the fact that the removal of TGF- $\beta$ from the medium significantly suppressed the Notch-mediated transcription of MMC marker genes. These results suggest that pericellular TGF- $\beta$ is required for Notch-mediated transcription of MMC marker genes and that Notch signaling acts to promote TGF- $\beta$ /SMAD signaling-dependent gene transcription. Next, by chromatin immunoprecipitation assays, we showed that Notch signaling significantly increased the levels of active histone marks at the promoter regions of Mcpt1 and Mcpt2. Furthermore, the nuclear accumulation of SMAD3 and SMAD4 was observed in BMMCs that were forced to express the active Notch2 intracellular domain, which translocated to the nucleus to form a transcription complex. Taken together, Notch and TGF- $\beta$ signaling play synergistic and interdependent roles in inducing the differentiation of MMCs (Figure 2) [68]. These roles may contribute to the rapid expansion of the number of MMCs during allergic mucosal inflammation.

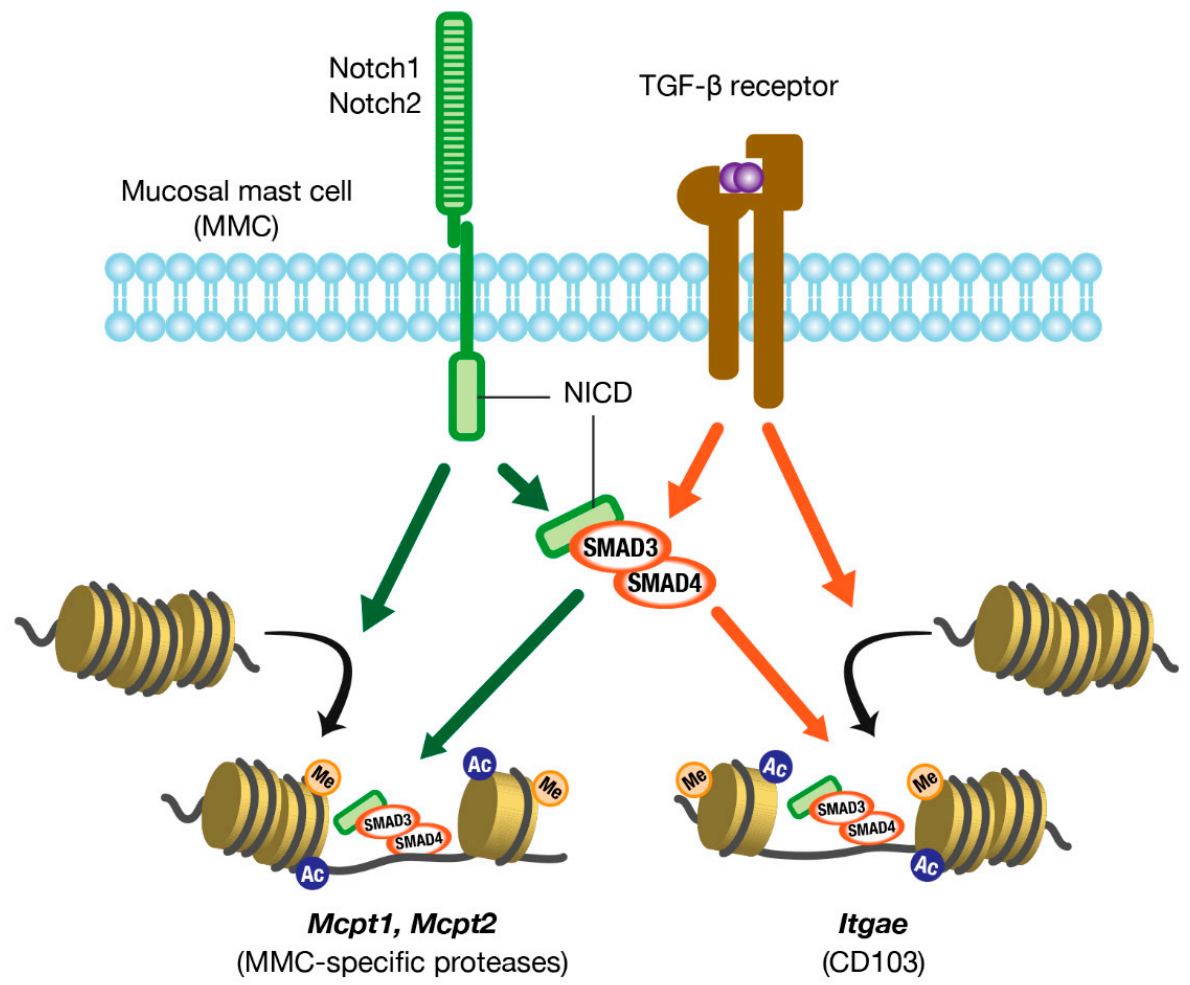

Figure 2. Molecular mechanisms of MMC marker gene expression. Notch and TGF- $\beta$ signaling act synergistically and interdependently in the expression of MMC marker genes. MMC, mucosal mast cell; TGF- $\beta$, transforming growth factor- $\beta$; NICD, Notch intracellular domain. 


\section{Inducers of MMC Expansion}

MMC hyperplasia in the intestinal mucosa in IgE-mediated food allergies probably involves both the recruitment of MCps and in situ MMC proliferation. Thus, MMC growth factors are thought to be abundant in inflamed mucosal tissues. In particular, IL-3, IL-4, IL-9, and stem cell factor (SCF) are known as major growth factors of MMCs (Figure 1). The survival and proliferation of mouse MMCs depends on the presence of IL-3. Since IL-3 is produced primarily by T cells, MMC proliferation is, therefore, T-cell-dependent [69]. In addition, IL-3-dependent MMC proliferation is further enhanced by IL-4 [70]. SCF, a ligand for c-Kit produced mainly by stromal cells and epithelial cells, is also an important growth factor for both mouse and human mast cells. It has been reported that SCF is critical for the development of MMC hyperplasia in murine models of food allergy and infection with intestinal parasites [71,72]. In addition, IL-4 markedly amplifies the SCF-dependent proliferation of human mast cells isolated from intestinal tissues [73]. Moreover, IL-4 has been shown to not only enhance IL-3- or SCF-dependent mast cell proliferation, but also to directly stimulate proliferation via STAT6 in a mouse mode of food allergies [74]. In food allergies, IL-4 is produced by basophils and IL-33-stimulated group 2 innate lymphoid cells (ILC2s) in addition to Th2 cells [75,76]. Abundant IL-4 stimulates IgE production by B cells and inhibits Treg functions, resulting in enhanced MMC activation. In humans, data from single-cell RNA sequencing analysis show a significant correlation between the number of mast cells in the tissue and the expression levels of IL-4-related genes. Moreover, IL-4 has also been shown to confer an inflammatory phenotype on $\mathrm{MC}_{\mathrm{T}}$ [77]. Therefore, IL-4 is a key determinant of MMC expansion in food allergies.

In addition to those cytokines, IL-9, previously described as mast cell growth-enhancing activity (MEA), is also an important cytokine that induces MMC hyperplasia in a mouse model of food allergy [78]. Although a well-known source of IL-9 is helper T cells, it has recently been shown that a population of MMCs, termed IL-9-producing MMCs (MMC9s), is a critical source of IL-9 in IgE-mediated food allergy [79,80]. MMC9s are generated from bone marrow-derived MCp in the presence of IL- 4 and produce prodigious amounts of IL-9 in response to IL-33 released from injured epithelial cells, leading to MMC expansion.

Taken together, IL-3 and SCF may play a fundamental role in mast cell survival and proliferation. IL-4 enhances the effects of those cytokines while conferring an inflammatory phenotype on MMCs. Inflammatory MMCs actively produce IL-9 to induce MMC expansion, resulting in increased susceptibility to IgE-mediated food allergy.

\section{MMCs as a Potential Therapeutic Target for the Treatment of Food Allergies}

\subsection{Blockade of Notch Signaling}

Notch signaling is a potent inducer of MMC differentiation. To investigate whether the symptoms of food allergies are attenuated by the inhibition of Notch signaling, we administered the Notch signaling inhibitor DAPT, also known as a $\gamma$-secretase inhibitor, to a mouse model of IgE-meditated food allergy sensitized with ovalbumin (OVA). The expansion of MMCs in the small intestine and colon was significantly suppressed in mice treated with DAPT during the effector phase. Predictably, the severity of allergic diarrhea and the degree of hypothermia induced by oral administration of OVA were lower in mice treated with DAPT than in the control mice. The concentration of serum OVA-specific IgE in DAPT-treated mice was the same level as in the control mice, indicating that the reduction in MMC numbers contributed to the attenuation of symptoms [63]. Since Notch signaling is not only involved in MMC differentiation but also in the differentiation of various immune cells, long-term administration of a Notch signaling inhibitor may lead to undesirable side effects in food-allergic patients. Therefore, the idea of administering a Notch signaling inhibitor to patients with food allergies is not very promising. However, these results suggest that the inhibition of MMC differentiation and the suppression of Notch target gene expression in mast cells can be effective in the treatment of IgE-mediated food allergies. 


\subsection{Blockade of IL-4 Signaling}

In allergic inflammation in both human and mouse mucosa, IL-4 is a key cytokine for inducing MMC expansion and conferring inflammatory phenotypes to MMCs. Thus, the blockade of IL-4 signaling may prevent MMC expansion in IgE-mediated food allergies. Dupilumab, a fully human monoclonal antibody against the IL-4 receptor $\alpha$ chain (IL-4R $\alpha$ ), has already been used to treat patients with severe atopic dermatitis (AD), asthma, and chronic rhinosinusitis with nasal polyposis (CRSwNP) [81]. IL-4R $\alpha$ is shared with IL-4 receptor and IL-13 receptor, and thus dupilumab blocks both IL-4 and IL-13 signaling. IL-4 and IL-13 are signature type 2 cytokines and exert diverse effects on multiple cells. IL-4 plays a critical role in Th2 differentiation in T cells and IgE class switching in B cells. IL-13 induces goblet cell hyperplasia and smooth muscle cell proliferation [82]. In addition, both IL-4 and IL-13 act on mast cells, basophils, eosinophils, macrophages, fibroblasts, epithelial cells, and keratinocytes [83]. Dwyer et al. [77] performed data analysis of singlecell RNA sequencing from a patient with CRSwNP evaluated before and after six weeks of treatment with dupilumab and found markedly reduced expression of IL17RB (encoding IL-25 receptor), a newly identified marker of human $\mathrm{MC}_{\mathrm{T}}$. This indicates that dupilumab also targets MMCs and may be effective in suppressing mucosal allergy inflammation caused by MMCs. At this time, there are only a few reports of food-allergic patients treated with dupilumab. Rial et al. [84] have recently reported that a 30-year-old woman with severe $\mathrm{AD}$ who had newly developed a food allergy to corn and nuts acquired a tolerance to these foods by treatment with dupilumab. This case report suggests that the blockade of IL-4 signaling may be effective in the treatment of food allergies, although it is unclear whether MMCs are the primary target.

IL-33 and IL-25 secreted by various cell types activate Th2-type cytokine production and exacerbate allergic diseases. The neutralization of these cytokines by specific antibodies has been shown to be effective in suppressing the Th2 immune responses [85]. Therefore, these cytokines, which enhance the production of IL-4 and IL-13, may also be potent therapeutic targets.

\subsection{Activation of an Inhibitory Receptor}

Mast cells express the inhibitory receptor CD300f, also known as leukocyte monoimmunoglobulin-like receptor 3 (LMIR3), on the cell surface. CD300f has two immunoreceptor tyrosine-based inhibitory motifs (ITIMs) and an immunoreceptor tyrosine-based switch motif (ITSM) in its intracellular region, which are phosphorylated upon binding to its ligand ceramide [86]. Src homology 2 domain-containing protein phosphatase (SHP)-1 and -2 , which are recruited to the phosphorylated ITIMs and ITSM, negatively regulate high-affinity IgE receptor FceRI-mediated signaling, resulting in the suppression of IgEmediated mast cell activation. Uchida et al. [87] have shown that CD300f is also expressed on the cell surface of MMCs, MMC9, and $\beta 7$ integrin ${ }^{+} \mathrm{MCp}$ in the small intestinal lamina propria in mice. In a mouse model of IgE-mediated food allergy, the serum level of mMCP-1, a marker of MMC activation, was higher in CD300f-deficient mice than in wildtype mice after oral allergen challenge. Moreover, food allergy responses, such as allergic diarrhea and the transient drop in body temperature induced by allergen challenge, were exacerbated in CD300f-deficient mice compared to wild-type mice. These results suggest that IgE/MMC-mediated food allergy reactions may be attenuated by the activation of CD300f. Based on this hypothesis, ceramide-containing vesicles were administrated to the mouse model of IgE-mediated food allergy. As expected, the food allergy responses were attenuated in mice pretreated with the vesicles. Therefore, CD300f is a potential therapeutic target for the treatment of IgE-mediated food allergies.

In addition to the inhibitory receptor, inhibitory cytokines, such as IL-37, may also function to suppress excessive activation of mast cells [88]. Thus, these natural inhibitors of immune responses could also be used as therapeutic agents. 


\section{Roles of MMCs in Oral Immunotherapy}

Oral immunotherapy (OIT) is a promising treatment for patients with food allergies to induce desensitization and eventually sustain unresponsiveness to food allergens. In general, the process of OIT is composed of an initial build-up in which the allergen is administered repeatedly with a gradual increase followed by a maintenance phase. The first goal of OIT is desensitization, which is defined as a lack of clinical reactivity to allergens and is maintained by regular allergen exposure. The efficacy of OIT for egg, milk, and peanuts has been demonstrated by many randomized placebo-controlled trials [89]. However, OIT also has the risks of adverse reactions, such as oral itching, eosinophilic gastrointestinal disorders, and anaphylaxis $[89,90]$. To mitigate the risks of OIT, there is great interest in developing approaches to effectively and safely induce desensitization.

\subsection{Harmful Effects of $M M C s$}

Undesirable allergic reactions during OIT are triggered by the IgE-mast cell axis. One approach to prevent these reactions is to use an anti-IgE antibody. Omalizumab is a humanized IgG1K monoclonal antibody that binds to the Fc region of human $\operatorname{IgE}$ and is currently applied for the treatment of severe uncontrolled asthma, allergic rhinitis, and chronic spontaneous urticaria [91-93]. This antibody blocks the interaction between IgE and FceRI and reduces the level of free $\operatorname{IgE}$ in circulation, preventing the development of IgE-mediated allergic reactions. The use of omalizumab with OIT has been investigated in several small trials for the treatment of milk, egg, and peanut allergies [94]. Notably, these trials have shown that the combination of omalizumab and OIT can not only reduce adverse events but also the time to acquisition of desensitization. These reports support the idea that the activation of mast cells, including MMCs, impairs the acquisition of desensitization to allergens. Therefore, blockade of the IgE-mast cell axis will improve the safety and efficacy of OIT.

\subsection{Helpful Effects of MMCs}

There are several reports on the mechanisms by which the early initiation phase of OIT induces desensitization. Displacement of the actin cytoskeleton in desensitized mast cells inhibits IgE-dependent calcium influx and thus suppresses mast cell degranulation [95]. Another report demonstrates that OIT-induced mast cell hyporesponsiveness is induced by enhanced internalization of IgE bound to the cell surface [96]. These studies indicate that mast cells become unresponsive to allergens, resulting in the suppression of the induction of allergic symptoms. In addition, it is believed that the expansion of the Treg population is involved in the acquisition of desensitization and/or sustained unresponsiveness to allergens in the late initiation phase of OIT $[97,98]$. The mechanism by which Treg expansion is induced in cases of successful OIT is poorly understood. Previous studies have shown that, under certain conditions, mast cells play a role in immunosuppression by producing cytokines, such as IL-2 and IL-10 [99,100]. IL-2 is essential for the proliferation, survival, maintenance, and functional capacity of Tregs, which constitutively express IL-2 receptor $\alpha$ chain (CD25) [101]. Although IL-10 is a well-known immunosuppressive cytokine produced by Tregs, it also plays an important role in the differentiation and functional capacity of Tregs themselves [102,103]. Takasato et al. [104,105] have demonstrated a helpful effect of MMCs in OIT using a mouse model of OIT. OIT shifted MMCs from pathogenic (or pro-allergic) status to regulatory (desensitization) status. OIT-induced desensitized MMCs contributed to the expansion of Tregs by releasing immunosuppressive cytokines, such as IL-2 and IL-10, in addition to reduced reactivity to allergens and the suppressed release of the Th2 cytokine, IL-4. These results provide new insights into the role of MMCs in the mucosal immune system.

The second goal of OIT is the acquisition of sustained unresponsiveness to allergens, which is the long-term loss of reactivity to allergens independent of continued exposure to them. However, current OIT therapy has not been able to efficiently induce sustained unresponsiveness for specific allergens to food-allergic patients $[89,106]$. A major problem is that 
the mechanism by which sustained unresponsiveness is induced by OIT remains unknown. We have recently shown that the expansion of immunosuppressive cells, including Tregs, IL-10-expressing Th2, and myeloid-derived suppressor cells (MDSCs), contributes to the establishment of sustained unresponsiveness by OIT, and that Notch signaling is involved in these expansion processes [107]. However, the roles of MMCs were not analyzed in this study, and thus further research is needed.

\section{Concluding Remarks}

In summary, intestinal MMCs play a central role in the development of food-induced disorders mediated by mast cell activation, including systemic food allergies. Mouse MMCs are induced to differentiate mainly by TGF- $\beta$ and Notch ligands, stimulated to proliferate rapidly by IL-4 and IL-9, and converted to an inflammatory phenotype by IL-4. Although there are still many unanswered questions about human mast cells, transcriptome and proteome analyses suggest that they are not so different from mouse mast cells [36]. Thus, these cytokines and ligands are potential therapeutic targets for food-induced disorders.

Recent advances have revealed that MMCs $\left(\mathrm{MC}_{\mathrm{T}}\right.$ in humans) are a distinctly different population from CTMCs $\left(\mathrm{MC}_{\mathrm{TC}}\right.$ in humans). However, the functions of MMCs are still poorly understood. The number of MMCs increases dramatically during mucosal allergic inflammation. However, are $\beta 7$ integrin ${ }^{+} \mathrm{MCp}$ the only source of MMCs? What happens to the expanded MMCs after the inflammation has ended? Food allergies in humans are often accompanied by cutaneous symptoms in addition to mucosal symptoms. Are MMCs involved in the induction of cutaneous symptoms such as erythema and urticaria? Food-induced disorders, including systemic food allergy, cause abdominal pain. How do MMCs and sensory nerves interact? Do MMCs contribute to the establishment of oral tolerance? MMCs may have as-yet-unidentified functions and roles that are unique to the mucosal immune system. Therefore, research focusing on MMCs will further advance the treatment of food-induced disorders.

Author Contributions: N.N. drafted the manuscript. N.N. and J.K. finished it. All authors have read and agreed to the published version of the manuscript.

Funding: This work was supported in part by JSPS KAKENHI Grant Number JP18K08416 (to N.N.).

Institutional Review Board Statement: All animal experiments were approved by the Institutional Review Board of Juntendo University (approval no. 290082, 300067, 310080, 2020058, and 2021082).

Informed Consent Statement: Not applicable.

Data Availability Statement: Not applicable.

Conflicts of Interest: The authors declare no conflict of interest.

\section{References}

1. Cohen, S.G. Food allergens: Landmarks along a historic trail. J. Allergy Clin. Immunol. 2008, 121, 1521-1524. [CrossRef]

2. Vassilopoulou, E.; Christoforou, C.; Andreou, E.; Heraclides, A. Effects of food allergy on the dietary habits and intake of primary schools cypriot children. Eur. Ann. Allergy Clin. Immunol. 2017, 49, 181-185. [CrossRef] [PubMed]

3. McNeil, B.D.; Pundir, P.; Meeker, S.; Han, L.; Undem, B.J.; Kulka, M.; Dong, X. Identification of a mast-cell-specific receptor crucial for pseudo-allergic drug reactions. Nature 2015, 519, 237-241. [CrossRef] [PubMed]

4. Takamori, A.; Izawa, K.; Kaitani, A.; Ando, T.; Okamoto, Y.; Maehara, A.; Tanabe, A.; Nagamine, M.; Yamada, H.; Uchida, S.; et al. Identification of inhibitory mechanisms in pseudo-allergy involving mrgprb2/mrgprx2-mediated mast cell activation. J. Allergy Clin. Immunol. 2019, 143, 1231-1235. [CrossRef] [PubMed]

5. Kim, H.S.; Kawakami, Y.; Kasakura, K.; Kawakami, T. Recent advances in mast cell activation and regulation. F1000Research 2020, 9. [CrossRef]

6. Osborne, N.J.; Koplin, J.J.; Martin, P.E.; Gurrin, L.C.; Lowe, A.J.; Matheson, M.C.; Ponsonby, A.L.; Wake, M.; Tang, M.L.; Dharmage, S.C.; et al. Prevalence of challenge-proven IgE-mediated food allergy using population-based sampling and predetermined challenge criteria in infants. J. Allergy Clin. Immunol. 2011, 127, e661-e662. [CrossRef]

7. Sicherer, S.H.; Sampson, H.A. Food allergy: A review and update on epidemiology, pathogenesis, diagnosis, prevention, and management. J. Allergy Clin. Immunol. 2018, 141, 41-58. [CrossRef]

8. Ebisawa, M.; Ito, K.; Fujisawa, T. Japanese guidelines for food allergy 2020. Allergol. Int. 2020, 69, 370-386. [CrossRef] 
9. Vale, S.L.; Lobb, M.; Netting, M.J.; Murray, K.; Clifford, R.; Campbell, D.E.; Salter, S.M. A systematic review of infant feeding food allergy prevention guidelines-Can we agree? World Allergy Organ. J. 2021, 14, 100550. [CrossRef] [PubMed]

10. Aguilera-Lizarraga, J.; Florens, M.V.; Viola, M.F.; Jain, P.; Decraecker, L.; Appeltans, I.; Cuende-Estevez, M.; Fabre, N.; Van Beek, K.; Perna, E.; et al. Local immune response to food antigens drives meal-induced abdominal pain. Nature 2021, 590, 151-156. [CrossRef] [PubMed]

11. Cuomo, R.; Andreozzi, P.; Zito, F.P.; Passananti, V.; De Carlo, G.; Sarnelli, G. Irritable bowel syndrome and food interaction. World J. Gastroenterol. 2014, 20, 8837-8845.

12. Fritscher-Ravens, A.; Pflaum, T.; Mösinger, M.; Ruchay, Z.; Röcken, C.; Milla, P.J.; Das, M.; Böttner, M.; Wedel, T.; Schuppan, D. Many patients with irritable bowel syndrome have atypical food allergies not associated with immunoglobulin E. Gastroenterology 2019, 157, 109-118. [CrossRef] [PubMed]

13. Brandt, E.B.; Strait, R.T.; Hershko, D.; Wang, Q.; Muntel, E.E.; Scribner, T.A.; Zimmermann, N.; Finkelman, F.D.; Rothenberg, M.E Mast cells are required for experimental oral allergen-induced diarrhea. J. Clin. Investig. 2003, 112, 1666-1677. [CrossRef]

14. Osterfeld, H.; Ahrens, R.; Strait, R.; Finkelman, F.D.; Renauld, J.C.; Hogan, S.P. Differential roles for the IL-9/IL-9 receptor alpha-chain pathway in systemic and oral antigen-induced anaphylaxis. J. Allergy Clin. Immunol. 2010, 125, 469-476. [CrossRef]

15. Ahrens, R.; Osterfeld, H.; Wu, D.; Chen, C.Y.; Arumugam, M.; Groschwitz, K.; Strait, R.; Wang, Y.H.; Finkelman, F.D.; Hogan, S.P. Intestinal mast cell levels control severity of oral antigen-induced anaphylaxis in mice. Am. J. Pathol. 2012, 180, 1535-1546. [CrossRef] [PubMed]

16. Nakamura, T.; Maeda, S.; Horiguchi, K.; Maehara, T.; Aritake, K.; Choi, B.I.; Iwakura, Y.; Urade, Y.; Murata, T. Pgd2 deficiency exacerbates food antigen-induced mast cell hyperplasia. Nat. Commun. 2015, 6, 7514. [CrossRef]

17. Vogel, P.; Janke, L.; Gravano, D.M.; Lu, M.; Sawant, D.V.; Bush, D.; Shuyu, E.; Vignali, D.A.A.; Pillai, A.; Rehg, J.E. Globule leukocytes and other mast cells in the mouse intestine. Vet. Pathol. 2018, 55, 76-97. [CrossRef]

18. Galli, S.J.; Borregaard, N.; Wynn, T.A. Phenotypic and functional plasticity of cells of innate immunity: Macrophages, mast cells and neutrophils. Nat. Immunol. 2011, 12, 1035-1044. [CrossRef]

19. Moon, T.C.; St Laurent, C.D.; Morris, K.E.; Marcet, C.; Yoshimura, T.; Sekar, Y.; Befus, A.D. Advances in mast cell biology: New understanding of heterogeneity and function. Mucosal Immunol. 2010, 3, 111-128. [CrossRef] [PubMed]

20. Brown, J.K.; Knight, P.A.; Pemberton, A.D.; Wright, S.H.; Pate, J.A.; Thornton, E.M.; Miller, H.R. Expression of integrin-alphae by mucosal mast cells in the intestinal epithelium and its absence in nematode-infected mice lacking the transforming growth factor-beta1-activating integrin alphavbeta6. Am. J. Pathol. 2004, 165, 95-106. [CrossRef]

21. Dwyer, D.F.; Austen, K.F. The discovery of discrete developmental pathways directing constitutive and induced mast cells in mice. J. Immunol. 2021, 207, 359-361. [CrossRef]

22. Bankova, L.G.; Dwyer, D.F.; Liu, A.Y.; Austen, K.F.; Gurish, M.F. Maturation of mast cell progenitors to mucosal mast cells during allergic pulmonary inflammation in mice. Mucosal Immunol. 2015, 8, 596-606. [CrossRef] [PubMed]

23. Gentek, R.; Ghigo, C.; Hoeffel, G.; Bulle, M.J.; Msallam, R.; Gautier, G.; Launay, P.; Chen, J.; Ginhoux, F.; Bajenoff, M. Hemogenic endothelial fate mapping reveals dual developmental origin of mast cells. Immunity 2018, 48, 1160-1171. [CrossRef] [PubMed]

24. Li, Z.; Liu, S.; Xu, J.; Zhang, X.; Han, D.; Liu, J.; Xia, M.; Yi, L.; Shen, Q.; Xu, S.; et al. Adult connective tissue-resident mast cells originate from late erythro-myeloid progenitors. Immunity 2018, 49, 640-653. [CrossRef] [PubMed]

25. Elieh Ali Komi, D.; Wöhrl, S.; Bielory, L. Mast cell biology at molecular level: A comprehensive review. Clin. Rev. Allergy Immunol. 2020, 58, 342-365. [CrossRef]

26. Mulloy, B.; Lever, R.; Page, C.P. Mast cell glycosaminoglycans. Glycoconj. J. 2017, 34, 351-361. [CrossRef] [PubMed]

27. Dahlin, J.S.; Malinovschi, A.; Öhrvik, H.; Sandelin, M.; Janson, C.; Alving, K.; Hallgren, J. Lin- cd34hi cd117int/hi fceri+ cells in human blood constitute a rare population of mast cell progenitors. Blood 2016, 127, 383-391. [CrossRef] [PubMed]

28. Zheng, S.; Papalexi, E.; Butler, A.; Stephenson, W.; Satija, R. Molecular transitions in early progenitors during human cord blood hematopoiesis. Mol. Syst. Biol. 2018, 14, e8041. [CrossRef]

29. Beil, W.J.; Schulz, M.; Wefelmeyer, U. Mast cell granule composition and tissue location-A close correlation. Histol. Histopathol. 2000, 15, 937-946. [PubMed]

30. Gurish, M.F.; Austen, K.F. Developmental origin and functional specialization of mast cell subsets. Immunity 2012, 37, 25-33. [CrossRef]

31. Ribatti, D. The staining of mast cells: A historical overview. Int. Arch. Allergy Immunol. 2018, 176, 55-60. [CrossRef] [PubMed]

32. Derakhshan, T.; Samuchiwal, S.K.; Hallen, N.; Bankova, L.G.; Boyce, J.A.; Barrett, N.A.; Austen, K.F.; Dwyer, D.F. Lineage-specific regulation of inducible and constitutive mast cells in allergic airway inflammation. J. Exp. Med. 2020, 218, e20200321. [CrossRef] [PubMed]

33. Cepek, K.L.; Shaw, S.K.; Parker, C.M.; Russell, G.J.; Morrow, J.S.; Rimm, D.L.; Brenner, M.B. Adhesion between epithelial cells and T lymphocytes mediated by E-cadherin and the alpha E beta 7 integrin. Nature 1994, 372, 190-193. [CrossRef]

34. Chen, C.C.; Grimbaldeston, M.A.; Tsai, M.; Weissman, I.L.; Galli, S.J. Identification of mast cell progenitors in adult mice. Proc. Natl. Acad. Sci. USA 2005, 102, 11408-11413. [CrossRef]

35. Metcalfe, D.D.; Baram, D.; Mekori, Y.A. Mast cells. Physiol. Rev. 1997, 77, 1033-1079. [CrossRef] [PubMed]

36. Plum, T.; Wang, X.; Rettel, M.; Krijgsveld, J.; Feyerabend, T.B.; Rodewald, H.R. Human mast cell proteome reveals unique lineage, putative functions, and structural basis for cell ablation. Immunity 2020, 52, 404-416.e405. [CrossRef] 
37. Ehrsam, C.; Rechenauer, T.; Allabauer, I.; Siebenlist, G.; Kaspar, S.; Rieger, D.; Schmid, M.; Rückel, A.; Woelfle, J.; Hartmann, A.; et al. Mucosal mast cell distribution in the gastrointestinal tract of children: A preliminary study for establishing reference values. J. Pediatr. Gastroenterol. Nutr. 2022, 74, 46-53. [CrossRef] [PubMed]

38. Guilarte, M.; Santos, J.; de Torres, I.; Alonso, C.; Vicario, M.; Ramos, L.; Martínez, C.; Casellas, F.; Saperas, E.; Malagelada, J.R. Diarrhoea-predominant ibs patients show mast cell activation and hyperplasia in the jejunum. Gut 2007, 56, 203-209. [CrossRef]

39. Hagel, A.F.; deRossi, T.; Zopf, Y.; Konturek, P.; Dauth, W.; Kressel, J.; Hahn, E.G.; Raithel, M. Mast cell tryptase levels in gut mucosa in patients with gastrointestinal symptoms caused by food allergy. Int. Arch. Allergy Immunol. 2013, 160, $350-355$. [CrossRef]

40. Bischoff, S.C. Physiological and pathophysiological functions of intestinal mast cells. Semin. Immunopathol. 2009, 31, 185-205. [CrossRef]

41. Reber, L.L.; Hernandez, J.D.; Galli, S.J. The pathophysiology of anaphylaxis. J. Allergy Clin. Immunol. 2017, 140, 335-348. [CrossRef]

42. Honda, K.; Arima, M.; Cheng, G.; Taki, S.; Hirata, H.; Eda, F.; Fukushima, F.; Yamaguchi, B.; Hatano, M.; Tokuhisa, T.; et al. Prostaglandin $\mathrm{d} 2$ reinforces th2 type inflammatory responses of airways to low-dose antigen through bronchial expression of macrophage-derived chemokine. J. Exp. Med. 2003, 198, 533-543. [CrossRef]

43. Schwartz, L.B. Diagnostic value of tryptase in anaphylaxis and mastocytosis. Immunol. Allergy Clin. N. Am. 2006, 26, 451-463. [CrossRef] [PubMed]

44. Nakae, S.; Ho, L.H.; Yu, M.; Monteforte, R.; Iikura, M.; Suto, H.; Galli, S.J. Mast cell-derived tnf contributes to airway hyperreactivity, inflammation, and th2 cytokine production in an asthma model in mice. J. Allergy Clin. Immunol. 2007, 120, 48-55. [CrossRef]

45. Wang, M.; Takeda, K.; Shiraishi, Y.; Okamoto, M.; Dakhama, A.; Joetham, A.; Gelfand, E.W. Peanut-induced intestinal allergy is mediated through a mast cell-IgE-FcepsilonRI-IL-13 pathway. J. Allergy Clin. Immunol. 2010, 126, 306-316.e12. [CrossRef] [PubMed]

46. Simons, F.E. Anaphylaxis. J. Allergy Clin. Immunol. 2010, 125, S161-S181. [CrossRef]

47. Raithel, M.; Hagel, A.; Albrecht, H.; Zopf, Y.; Naegel, A.; Baenkler, H.W.; Buchwald, F.; Schultis, H.W.; Kressel, J.; Hahn, E.G.; et al. Excretion of urinary histamine and n-tele methylhistamine in patients with gastrointestinal food allergy compared to non-allergic controls during an unrestricted diet and a hypoallergenic diet. BMC Gastroenterol. 2015, 15, 41. [CrossRef] [PubMed]

48. Ruëff, F.; Przybilla, B.; Biló, M.B.; Müller, U.; Scheipl, F.; Aberer, W.; Birnbaum, J.; Bodzenta-Lukaszyk, A.; Bonifazi, F.; Bucher, C.; et al. Predictors of severe systemic anaphylactic reactions in patients with hymenoptera venom allergy: Importance of baseline serum tryptase-a study of the european academy of allergology and clinical immunology interest group on insect venom hypersensitivity. J. Allergy Clin. Immunol. 2009, 124, 1047-1054. [CrossRef]

49. Golden, D.B.K.; Carter, M.C. Insect sting anaphylaxis-or mastocytosis-or something else? J. Allergy Clin. Immunol. Pract. 2019, 7 , 1117-1123. [CrossRef]

50. Castells, M. Diagnosis and management of anaphylaxis in precision medicine. J. Allergy Clin. Immunol. 2017, 140, 321-333. [CrossRef]

51. Maeda, S.; Nakamura, T.; Harada, H.; Tachibana, Y.; Aritake, K.; Shimosawa, T.; Yatomi, Y.; Murata, T. Prostaglandin D2 metabolite in urine is an index of food allergy. Sci. Rep. 2017, 7, 17687. [CrossRef]

52. Inagaki, S.; Maeda, S.; Narita, M.; Nakamura, T.; Shimosawa, T.; Murata, T.; Ohya, Y. Urinary pgdm, a prostaglandin D2 metabolite, is a novel biomarker for objectively detecting allergic reactions of food allergy. J. Allergy Clin. Immunol. 2018, 142, 1634-1636. [CrossRef]

53. Patil, S.U.; Bunyavanich, S.; Berin, M.C. Emerging food allergy biomarkers. J. Allergy Clin. Immunol. Pract. 2020, 8, $2516-2524$. [CrossRef]

54. Crestani, E.; Harb, H.; Charbonnier, L.M.; Leirer, J.; Motsinger-Reif, A.; Rachid, R.; Phipatanakul, W.; Kaddurah-Daouk, R.; Chatila, T.A. Untargeted metabolomic profiling identifies disease-specific signatures in food allergy and asthma. J. Allergy Clin. Immunol. 2020, 145, 897-906. [CrossRef] [PubMed]

55. Miller, H.R.; Wright, S.H.; Knight, P.A.; Thornton, E.M. A novel function for transforming growth factor-beta1: Upregulation of the expression and the IgE-independent extracellular release of a mucosal mast cell granule-specific beta-chymase, mouse mast cell protease-1. Blood 1999, 93, 3473-3486. [CrossRef]

56. Wright, S.H.; Brown, J.; Knight, P.A.; Thornton, E.M.; Kilshaw, P.J.; Miller, H.R. Transforming growth factor-beta1 mediates coexpression of the integrin subunit alphae and the chymase mouse mast cell protease- 1 during the early differentiation of bone marrow-derived mucosal mast cell homologues. Clin. Exp. Allergy 2002, 32, 315-324. [CrossRef] [PubMed]

57. Kasakura, K.; Nagata, K.; Miura, R.; Iida, M.; Nakaya, H.; Okada, H.; Arai, T.; Arai, T.; Kawakami, Y.; Kawakami, T.; et al Cooperative regulation of the mucosal mast cell-specific protease genes mcpt1 and mcpt2 by gata and smad transcription factors. J. Immunol. 2020, 204, 1641-1649. [CrossRef] [PubMed]

58. Ghildyal, N.; McNeil, H.P.; Stechschulte, S.; Austen, K.F.; Silberstein, D.; Gurish, M.F.; Somerville, L.L.; Stevens, R.L. IL-10 induces transcription of the gene for mouse mast cell protease-1, a serine protease preferentially expressed in mucosal mast cells of trichinella spiralis-infected mice. J. Immunol. 1992, 149, 2123-2129.

59. Ghildyal, N.; Friend, D.S.; Nicodemus, C.F.; Austen, K.F.; Stevens, R.L. Reversible expression of mouse mast cell protease 2 mrna and protein in cultured mast cells exposed to IL-10. J. Immunol. 1993, 151, 3206-3214. [PubMed] 
60. Scott, C.L.; Aumeunier, A.M.; Mowat, A.M. Intestinal cd103+ dendritic cells: Master regulators of tolerance? Trends Immunol. 2011, 32, 412-419. [CrossRef]

61. Bain, C.C.; Montgomery, J.; Scott, C.L.; Kel, J.M.; Girard-Madoux, M.J.H.; Martens, L.; Zangerle-Murray, T.F.P.; Ober-Blobaum, J.; Lindenbergh-Kortleve, D.; Samsom, J.N.; et al. Tgfbetar signalling controls cd103+cd11b+ dendritic cell development in the intestine. Nat. Commun. 2017, 8, 620. [CrossRef]

62. Tordesillas, L.; Berin, M.C. Mechanisms of oral tolerance. Clin. Rev. Allergy Immunol. 2018, 55, 107-117. [CrossRef]

63. Honjo, A.; Nakano, N.; Yamazaki, S.; Hara, M.; Uchida, K.; Kitaura, J.; Nishiyama, C.; Yagita, H.; Ohtsuka, Y.; Ogawa, H.; et al Pharmacologic inhibition of notch signaling suppresses food antigen-induced mucosal mast cell hyperplasia. J. Allergy Clin. Immunol. 2017, 139, 987-996. [CrossRef]

64. Tanigaki, K.; Honjo, T. Regulation of lymphocyte development by notch signaling. Nat. Immunol. 2007, 8, 451-456. [CrossRef]

65. Osborne, B.A.; Minter, L.M. Notch signalling during peripheral T-cell activation and differentiation. Nat. Rev. Immunol. 2007, 7, 64-75. [CrossRef]

66. Nakano, N.; Nishiyama, C.; Yagita, H.; Koyanagi, A.; Akiba, H.; Chiba, S.; Ogawa, H.; Okumura, K. Notch signaling confers antigen-presenting cell functions on mast cells. J. Allergy Clin. Immunol. 2009, 123, 74-81. [CrossRef]

67. Mokrani, M.; Klibi, J.; Bluteau, D.; Bismuth, G.; Mami-Chouaib, F. Smad and nfat pathways cooperate to induce cd103 expression in human cd8 T lymphocytes. J. Immunol. 2014, 192, 2471-2479. [CrossRef]

68. Nakano, N.; Saida, K.; Hara, M.; Izawa, K.; Ando, T.; Kaitani, A.; Kasakura, K.; Yashiro, T.; Nishiyama, C.; Ogawa, H.; et al Mucosal mast cell-specific gene expression is promoted by interdependent action of notch and tgf- $\beta$ signaling. J. Immunol. 2021, 207, 3098-3106. [CrossRef]

69. Guy-Grand, D.; Dy, M.; Luffau, G.; Vassalli, P. Gut mucosal mast cells. Origin, traffic, and differentiation. J. Exp. Med. 1984, 160, 12-28. [CrossRef]

70. Schmitt, E.; Fassbender, B.; Beyreuther, K.; Spaeth, E.; Schwarzkopf, R.; Rüde, E. Characterization of a T cell-derived lymphokine that acts synergistically with IL 3 on the growth of murine mast cells and is identical with IL 4. Immunobiology 1987, 174, 406-419. [CrossRef]

71. Newlands, G.F.; Coulson, P.S.; Wilson, R.A. Stem cell factor dependent hyperplasia of mucosal-type mast cells but not eosinophils in schistosoma mansoni-infected rats. Parasite Immunol. 1995, 17, 595-598. [CrossRef]

72. Ptaschinski, C.; Rasky, A.J.; Fonseca, W.; Lukacs, N.W. Stem cell factor neutralization protects from severe anaphylaxis in a murine model of food allergy. Front. Immunol. 2021, 12, 604192. [CrossRef]

73. Lorentz, A.; Bischoff, S.C. Regulation of human intestinal mast cells by stem cell factor and IL-4. Immunol. Rev. 2001, 179, 57-60. [CrossRef]

74. Burton, O.T.; Darling, A.R.; Zhou, J.S.; Noval-Rivas, M.; Jones, T.G.; Gurish, M.F.; Chatila, T.A.; Oettgen, H.C. Direct effects of IL-4 on mast cells drive their intestinal expansion and increase susceptibility to anaphylaxis in a murine model of food allergy. Mucosal Immunol. 2013, 6, 740-750. [CrossRef]

75. Noval Rivas, M.; Burton, O.T.; Oettgen, H.C.; Chatila, T. IL-4 production by group 2 innate lymphoid cells promotes food allergy by blocking regulatory T-cell function. J. Allergy Clin. Immunol. 2016, 138, 801-811. [CrossRef]

76. Kashiwakura, J.I.; Ando, T.; Karasuyama, H.; Kubo, M.; Matsumoto, K.; Matsuda, T.; Kawakami, T. The basophil-IL-4-mast cell axis is required for food allergy. Allergy 2019, 74, 1992-1996. [CrossRef]

77. Dwyer, D.F.; Ordovas-Montanes, J.; Allon, S.J.; Buchheit, K.M.; Vukovic, M.; Derakhshan, T.; Feng, C.; Lai, J.; Hughes, T.K.; Nyquist, S.K.; et al. Human airway mast cells proliferate and acquire distinct inflammation-driven phenotypes during type 2 inflammation. Sci. Immunol. 2021, 6, eabb7221. [CrossRef] [PubMed]

78. Forbes, E.E.; Groschwitz, K.; Abonia, J.P.; Brandt, E.B.; Cohen, E.; Blanchard, C.; Ahrens, R.; Seidu, L.; McKenzie, A.; Strait, R.; et al. IL-9- and mast cell-mediated intestinal permeability predisposes to oral antigen hypersensitivity. J. Exp. Med. 2008, 205, 897-913. [CrossRef] [PubMed]

79. Chen, C.Y.; Lee, J.B.; Liu, B.; Ohta, S.; Wang, P.Y.; Kartashov, A.V.; Mugge, L.; Abonia, J.P.; Barski, A.; Izuhara, K.; et al. Induction of interleukin-9-producing mucosal mast cells promotes susceptibility to IgE-mediated experimental food allergy. Immunity 2015, 43, 788-802. [CrossRef] [PubMed]

80. Tomar, S.; Ganesan, V.; Sharma, A.; Zeng, C.; Waggoner, L.; Smith, A.; Kim, C.H.; Licona-Limón, P.; Reinhardt, R.L.; Flavell, R.A.; et al. IL-4-BATF signaling directly modulates IL-9 producing mucosal mast cell (MMC9) function in experimental food allergy. $J$. Allergy Clin. Immunol. 2021, 147, 280-295. [CrossRef]

81. Harb, H.; Chatila, T.A. Mechanisms of dupilumab. Clin. Exp. Allergy 2020, 50, 5-14. [CrossRef]

82. Corren, J. Role of interleukin-13 in asthma. Curr. Allergy Asthma Rep. 2013, 13, 415-420. [CrossRef]

83. Matsunaga, K.; Katoh, N.; Fujieda, S.; Izuhara, K.; Oishi, K. Dupilumab: Basic aspects and applications to allergic diseases. Allergol. Int. 2020, 69, 187-196. [CrossRef]

84. Rial, M.J.; Barroso, B.; Sastre, J. Dupilumab for treatment of food allergy. J. Allergy Clin. Immunol. Pract. 2019, 7, 673-674. [CrossRef]

85. Yang, C.; Chen, N.; Tang, X.L.; Qian, X.H.; Cai, C.P. Immunomodulatory effects of IL-33 and IL-25 in an ovalbumin-induced allergic rhinitis mouse model. J. Biol. Regul. Homeost. Agents 2021, 35, 571-581. [PubMed] 
86. Izawa, K.; Yamanishi, Y.; Maehara, A.; Takahashi, M.; Isobe, M.; Ito, S.; Kaitani, A.; Matsukawa, T.; Matsuoka, T.; Nakahara, F.; et al. The receptor lmir3 negatively regulates mast cell activation and allergic responses by binding to extracellular ceramide. Immunity 2012, 37, 827-839. [CrossRef]

87. Uchida, S.; Izawa, K.; Ando, T.; Yamada, H.; Uchida, K.; Negishi, N.; Kaitani, A.; Maehara, A.; Nagamine, M.; Kamei, A.; et al. $\mathrm{Cd} 300 \mathrm{f}$ is a potential therapeutic target for the treatment of food allergy. Allergy 2020, 75, 471-474. [CrossRef]

88. Compton, R.A.; Lonergan, A.R.; Tsillioni, I.; Conti, P.; Ronconi, G.; Lauritano, D.; Rebeiz, E.E.; Theoharides, T.C. Neurohormonal markers in chronic rhinosinusitis. J. Biol. Regul. Homeost. Agents 2021, 35, 901-908.

89. Wood, R.A. Food allergen immunotherapy: Current status and prospects for the future. J. Allergy Clin. Immunol. 2016, 137, 973-982. [CrossRef] [PubMed]

90. Goldberg, M.R.; Elizur, A.; Nachshon, L.; Appel, M.Y.; Levy, M.B.; Golobov, K.; Goldberg, R.; Stein, M.; Rothenberg, M.E.; Katz, Y. Oral immunotherapy-induced gastrointestinal symptoms and peripheral blood eosinophil responses. J. Allergy Clin. Immunol. 2017, 139, 1388-1390. [CrossRef] [PubMed]

91. Wise, S.K.; Lin, S.Y.; Toskala, E.; Orlandi, R.R.; Akdis, C.A.; Alt, J.A.; Azar, A.; Baroody, F.M.; Bachert, C.; Canonica, G.W.; et al. International consensus statement on allergy and rhinology: Allergic rhinitis. Int. Forum Allergy Rhinol. 2018, 8, 108-352.

92. Okayama, Y.; Matsumoto, H.; Odajima, H.; Takahagi, S.; Hide, M.; Okubo, K. Roles of omalizumab in various allergic diseases. Allergol. Int. 2020, 69, 167-177. [CrossRef]

93. Ando, T.; Kitaura, J. Tuning IgE: IgE-associating molecules and their effects on IgE-dependent mast cell reactions. Cells 2021, 10, 1697. [CrossRef] [PubMed]

94. Dantzer, J.A.; Wood, R.A. The use of omalizumab in allergen immunotherapy. Clin. Exp. Allergy 2018, 48, 232-240. [CrossRef] [PubMed]

95. Ang, W.X.; Church, A.M.; Kulis, M.; Choi, H.W.; Burks, A.W.; Abraham, S.N. Mast cell desensitization inhibits calcium flux and aberrantly remodels actin. J. Clin. Investig. 2016, 126, 4103-4118. [CrossRef]

96. Oka, T.; Rios, E.J.; Tsai, M.; Kalesnikoff, J.; Galli, S.J. Rapid desensitization induces internalization of antigen-specific IgE on mouse mast cells. J. Allergy Clin. Immunol. 2013, 132, 922-932. [CrossRef]

97. Kulis, M.D.; Patil, S.U.; Wambre, E.; Vickery, B.P. Immune mechanisms of oral immunotherapy. J. Allergy Clin. Immunol. 2018, 141, 491-498. [CrossRef] [PubMed]

98. Eiwegger, T.; Hung, L.; San Diego, K.E.; O'Mahony, L.; Upton, J. Recent developments and highlights in food allergy. Allergy 2019, 74, 2355-2367. [CrossRef] [PubMed]

99. Leveson-Gower, D.B.; Sega, E.I.; Kalesnikoff, J.; Florek, M.; Pan, Y.; Pierini, A.; Galli, S.J.; Negrin, R.S. Mast cells suppress murine gvhd in a mechanism independent of cd4+cd25+ regulatory T cells. Blood 2013, 122, 3659-3665. [CrossRef] [PubMed]

100. Morita, H.; Arae, K.; Unno, H.; Miyauchi, K.; Toyama, S.; Nambu, A.; Oboki, K.; Ohno, T.; Motomura, K.; Matsuda, A.; et al An interleukin-33-mast cell-interleukin-2 axis suppresses papain-induced allergic inflammation by promoting regulatory $\mathrm{T}$ cell numbers. Immunity 2015, 43, 175-186. [CrossRef]

101. Abbas, A.K.; Trotta, E.; RSimeonov, D.; Marson, A.; Bluestone, J.A. Revisiting IL-2: Biology and therapeutic prospects. Sci. Immunol. 2018, 3, eaat1482. [CrossRef] [PubMed]

102. Hsu, P.; Santner-Nanan, B.; Hu, M.; Skarratt, K.; Lee, C.H.; Stormon, M.; Wong, M.; Fuller, S.J.; Nanan, R. IL-10 potentiates differentiation of human induced regulatory T cells via stat3 and foxo1. J. Immunol. 2015, 195, 3665-3674. [CrossRef] [PubMed]

103. Park, M.J.; Lee, S.H.; Kim, E.K.; Lee, E.J.; Baek, J.A.; Park, S.H.; Kwok, S.K.; Cho, M.L. Interleukin-10 produced by myeloid-derived suppressor cells is critical for the induction of tregs and attenuation of rheumatoid inflammation in mice. Sci. Rep. 2018, 8, 3753. [CrossRef]

104. Takasato, Y.; Kurashima, Y.; Kiuchi, M.; Hirahara, K.; Murasaki, S.; Arai, F.; Izawa, K.; Kaitani, A.; Shimada, K.; Saito, Y.; et al. Orally desensitized mast cells form a regulatory network with treg cells for the control of food allergy. Mucosal Immunol. 2021, 14, 640-651. [CrossRef]

105. Zhang, Z.; Kurashima, Y. Two sides of the coin: Mast cells as a key regulator of allergy and acute/chronic inflammation. Cells 2021, 10, 1615. [CrossRef]

106. Burks, A.W.; Jones, S.M.; Wood, R.A.; Fleischer, D.M.; Sicherer, S.H.; Lindblad, R.W.; Stablein, D.; Henning, A.K.; Vickery, B.P.; Liu, A.H.; et al. Oral immunotherapy for treatment of egg allergy in children. N. Engl. J. Med. 2012, 367, 233-243. [CrossRef] [PubMed]

107. Yoneyama, T.; Nakano, N.; Hara, M.; Yamada, H.; Izawa, K.; Uchida, K.; Kaitani, A.; Ando, T.; Kitaura, J.; Ohtsuka, Y.; et al. Notch signaling contributes to the establishment of sustained unresponsiveness to food allergens by oral immunotherapy. J. Allergy Clin. Immunol. 2021, 147, 1063-1076. [CrossRef] 